Novia Wijaya, Lusia Savitri Setyo Utami: Pengaruh Penyampaian Informasi pada Aplikasi TikTok terhadap Perilaku Konsumtif Generasi Z

\title{
Pengaruh Penyampaian Informasi pada Aplikasi TikTok terhadap Perilaku Konsumtif Generasi Z
}

\author{
Novia Wijaya, Lusia Savitri Setyo Utami \\ novia.915170019@stu.untar.ac.id,lusias@fikom.untar.ac.id
}

Fakultas Ilmu Komunikasi Universitas Tarumanagara

\begin{abstract}
During the COVID-19 pandemic, people were required to stay at home that makes people need entertainment. The TikTok application is one of the applications that are currently viral during the COVID-19 pandemic. Users can express their creativity in the TikTok application. Marketing of a product can also be done on the TikTok application. Users of the TikTok application are dominated by generation Z. Generation Z is born in 1996-2009. Everyone can easily access the TikTok application. This quantitative research aims to determine whether or not the delivery of information on the TikTok application has an effect on the consumptive behavior of Generation $Z$ and how much influence it has. This research's theoretical basis is information integration theory, integrated marketing communication (marketing mix, digital marketing), social media marketing, and consumptive behavior. The research method used in this research is a survey and data collected through a questionnaire. This study indicates that there is an effect of delivering information on the consumptive behavior of Generation $Z$ by 37.4\%. The dimension that most influence is the dimension of clarity of information on the variables of information delivery. In the consumptive behavior variable, the most affected dimensions are cost efficiency and following the fashion.
\end{abstract}

Keywords: digital marketing, information integration, marketing communication, social media marketing, tiktok application

\begin{abstract}
Abstrak
Pada masa pandemi COVID-19, masyarakat diharuskan untuk di rumah saja. Hal tersebut membuat masyarakat butuh akan hiburan. Aplikasi TikTok adalah salah satu aplikasi yang sedang viral pada masa pandemi COVID-19 ini. Pengguna dapat menuangkan kreativitasnya pada aplikasi TikTok. Pemasaran suatu produk pun dapat dilakukan pada aplikasi TikTok. Pengguna pada aplikasi TikTok didominasi oleh generasi Z. Generasi $\mathrm{Z}$ adalah generasi yang lahir pada tahun 1996-2009. Aplikasi TikTok dapat dengan mudah diakses oleh semua orang. Tujuan dari penelitian kuantitatif ini adalah untuk mengetahui ada atau tidaknya pengaruh penyampaian informasi pada aplikasi TikTok terhadap perilaku konsumtif generasi Z dan juga seberapa besar pengaruh tersebut. Landasan teori yang digunakan dalam penelitian ini adalah teori integrasi informasi (information integration theory), komunikasi pemasaran terpadu (marketing mix, digital marketing), social media marketing, dan perilaku konsumtif. Metode penelitian yang digunakan dalam penelitian ini adalah survey dan data-data yang dikumpulkan melalui kuesioner. Hasil penelitian ini menunjukan bahwa terdapat pengaruh penyampaian informasi terhadap perilaku konsumtif generasi $\mathrm{Z}$ sebesar $37.4 \%$. Dimensi yang paling mempengaruhi adalah dimensi kejelasan informasi pada variabel penyampaian informasi. Pada variabel perilaku konsumtif, dimensi yang paling dipengaruhi adalah dimensi inefisiensi biaya dan mengikuti mode.
\end{abstract}


Kata Kunci: aplikasi tiktok, integrasi informasi, komunikasi pemasaran, pemasaran digital, pemasaran media sosial

\section{Pendahuluan}

Perkembangan zaman dari tahun ke tahun tidak terlepas dari internet. Dengan hadirnya internet, maka teknologi komunikasi juga semakin berkembang. Media sosial merupakan salah satu inovasi dari perkembangan teknologi komunikasi. Media sosial menurut Kotler \& Keller (2012) adalah tempat seseorang menyampaikan informasi berupa pesan, gambar, audio, ataupun video. Salah satu media sosial yang sedang viral pada masa pandemi COVID-19 adalah aplikasi TikTok. Dilansir dari TikTok.com, TikTok adalah salah satu bentuk media massa yang menyediakan video dengan durasi singkat yang bertujuan untuk menginspirasi kreativitas dan membawa kegembiraan bagi penggunanya.

TikTok juga mendefinisikan bahwa aplikasinya memberikan kebebasan bagi pengguna untuk menuangkan kreativitasnya agar dapat mempersuasi pengguna lain. TikTok menyuguhkan berbagai macam efek untuk memperindah hasil dari videonya, seperti efek suara, transisi, filter-filter 3D dan warna. Pada masa pandemi COVID-19 ini, masyarakat diharuskan untuk di rumah saja. Hal tersebut tentunya berdampak pada aktivitas dan juga hiburan masyarakat, terutama pada generasi $\mathrm{Z}$ yang lahir pada tahun 1996-2009.

Menurut Julia Chan, Mobile Insights Analyst, dikutip dari keterangan resmi perusahaan, negara-negara dengan pemasangan aplikasi TikTok terbanyak selama periode Juli 2020 adalah pengguna berbasis di Amerika Serikat dengan 9,7 persen dan Indonesia dengan 8,5 persen.

Gambar 1. 10 Aplikasi dengan Angka Unduhan Tertinggi Juli 2020.

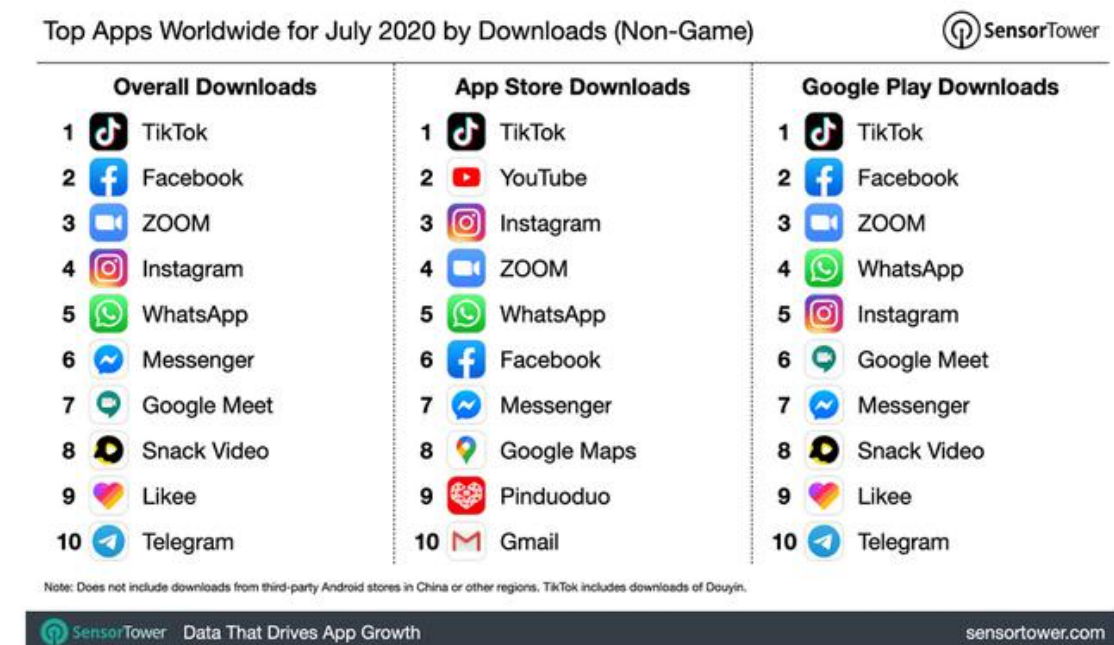

Sumber: Liputan6.com

Menurut Donny Eryastha selaku Head of Public Policy TikTok Indonesia dalam SindoNews.com, pengguna aplikasi TikTok di Indonesia didominasi oleh generasi Z . Dalam Liputan6.com, dikutip dari laman Forbes pada Agustus 2020, lebih dari 60 persen 
Novia Wijaya, Lusia Savitri Setyo Utami: Pengaruh Penyampaian Informasi pada Aplikasi TikTok terhadap Perilaku Konsumtif Generasi Z

pengguna TikTok terdiri dari generasi Z. Generasi Z juga disebut sebagai generasi internet yang terampil di dunia digital dan cenderung lebih ekspresif.

TikTok dapat dengan mudah diakses oleh semua orang dari seluruh dunia melalui smartphone. Video yang diunggah ke TikTok juga beragam, mulai dari konten Point of View, lipsync, parodi, menari dengan gerakan yang sedang trend, dan juga penyampaian berbagai informasi. Penyampaian informasi pada TikTok biasanya mengenai rekomendasi restoran, tempat hiburan, skincare, outfit, aksesoris, dan berbagai rekomendasi lainnya. Penyampaian informasi tersebut dilakukan dengan video singkat dan dibuat semenarik mungkin agar dapat menarik khalayak. Teori dan konsep yang digunakan dalam penelitian ini adalah:

1. Teori Integrasi Informasi (Information Integration Theory)

Pada masa pandemi COVID-19, orang lebih banyak berjualan secara online, sehingga penyampaian informasi mengenai pemasaran suatu produk akan berdampak pada pembelian produk tersebut. Penyampaian informasi menjadi faktor apakah produk tersebut akan viral atau tidak. Menurut Littlejohn, penyampaian informasi pada Aplikasi TikTok dapat dilihat dalam teori Integrasi Informasi (Information Integration Theory) yang berasumsi bahwa metode integrasi informasi komunikator berfokus pada bagaimana kita mengumpulkan dan mengatur informasi tentang semua orang, objek, situasi, dan pemikiran. Informasi ini membentuk sikap atau kecenderungan untuk bertindak atas suatu objek secara positif atau negatif.

2. Komunikasi Pemasaran Terpadu

Pemasaran didefiniskan dalam konsep Komunikasi Pemasaran Terpadu. Menurut Kotler \& Keller (2012), Komunikasi Pemasaran Terpadu adalah perusahaan yang secara langsung atau tidak langsung berusaha menginformasikan, membujuk dan mengingatkan konsumen tentang produk atau merek yang dijual. Dalam kajian pemasaran, kegiatan promosi yang efektif dan efisien dapat dimasukkan sebagai bagian dari konsep bauran komunikasi pemasaran atau biasa yang disebut dengan marketing communication mix.

3. Marketing Mix (Digital Marketing)

Dalam marketing communication mix terdapat digital marketing. Menurut Ridwan Sanjaya dan Josua Tarigan, digital marketing adalah penggunaan media berbasis web (seperti blog, website, email, adwords atau jejaring sosial) untuk kegiatan pemasaran dan pengenalan merek.

4. Social Media Marketing

Pada awalnya, TikTok hanya dijadikan sebagai media sosial. Dalam perkembangannya, TikTok dapat juga dijadikan sebagai media sosial marketing. Aktivitas penyampaian informasi dalam TikTok digolongkan ke dalam social media marketing. Menurut Moyan (2014), social media marketing adalah model pemasaran internet yang mencapai tujuan pemasaran dengan berpartisipasi di berbagai media sosial.

Penelitian ini bertujuan untuk mengetahui ada atau tidaknya pengaruh penyampaian informasi pada aplikasi TikTok terhadap perilaku konsumtif generasi $Z$ dan mengetahui seberapa besar pengaruh tersebut. Hipotesis dalam penelitian ini adalah:

a. $\mathrm{HO}=$ tidak ada pengaruh antara penyampaian informasi pada aplikasi TikTok terhadap perilaku konsumtif generasi $Z$.

b. $\mathrm{H} 1$ = ada pengaruh antara penyampaian informasi pada aplikasi TikTok terhadap perilaku konsumtif generasi $Z$. 


\section{Metode Penelitian}

Pendekatan penelitian yang digunakan oleh peneliti adalah pendekatan kuantitatif. Metode penelitian yang digunakan peneliti dalam penelitian ini adalah survey. Populasi yang diambil dalam penelitian ini adalah generasi $\mathrm{Z}$. Jumlah responden yang diambil dalam penelitian ini berdasarkan banyaknya indikator pada penelitian lalu dikali 5 (Hair et al. dalam Dwi Aryani dan Febrina Rosinta, 2010). Indikator dalam penelitian ini berjumlah 24 indikator. Maka, perhitungannya adalah 24x5, yaitu sebanyak 120 responden.

Metode yang digunakan dalam penelitian ini adalah nonprobability sampling. Nonprobability sampling menurut Sugiyono (2020) adalah teknik pengambilan sampel yang tidak dapat memberikan peluang yang sama bagi setiap elemen atau anggota populasi yang dipilih sebagai sampel. Karena metode penelitian ini menggunakan nonprobability sampling, unsur populasi sudah direncanakan oleh peneliti, tidak dipilih secara acak. Dalam penelitian ini, data yang digunakan adalah data primer. Metode pengumpulan data menggunakan kuesioner dan skala likert. Pengolahan data dalam penelitian ini menggunakan program Statistical Product and Service Solutions (SPSS), editing, coding, dan tabulasi. Untuk teknik analisis data dalam penelitian ini adalah uji hipotesis, analisis regresi sederhana, uji normalitas, koefisien determinasi. Sedangkan, teknik pengabsahan data menggunakan uji validitas dan uji reliabilitas.

\section{Hasil Temuan dan Diskusi}

Teknik analisis data dalam penelitian ini menggunakan SPSS versi 22 dengan beberapa uji sebagai berikut:

Tabel 1. Hasil Uji Validitas

\begin{tabular}{ccccc} 
Variabel & $\begin{array}{c}\text { Butir } \\
\text { Indikator }\end{array}$ & $\begin{array}{c}\text { Pearson } \\
\text { Correlation }\end{array}$ & Signifikansi & Keterangan \\
\hline $\begin{array}{c}\text { Penyampaian } \\
\text { Informasi }\end{array}$ & $\mathrm{P} 1$ & 0,648 & 0.00 & Valid \\
\hline & $\mathrm{P} 2$ & 0.583 & 0.00 & Valid \\
\cline { 2 - 5 } & $\mathrm{P} 3$ & 0.648 & 0.00 & Valid \\
\hline & $\mathrm{P} 4$ & 0.696 & 0.00 & Valid \\
\hline & $\mathrm{P} 5$ & 0.637 & 0.00 & Valid \\
\cline { 2 - 5 } & $\mathrm{P} 6$ & 0.631 & 0.00 & Valid \\
\cline { 2 - 5 } & $\mathrm{P} 7$ & 0.732 & 0.00 & Valid \\
\hline & $\mathrm{P} 8$ & 0.622 & 0.00 & Valid \\
\hline & $\mathrm{P} 9$ & 0.723 & 0.00 & Valid \\
\hline Perilaku Konsumtif & $\mathrm{P} 10$ & 0.702 & 0.00 & Valid \\
\hline & $\mathrm{P} 11$ & 0.671 & 0.00 & Valid \\
\hline & $\mathrm{P} 12$ & 0.671 & 0.00 & Valid \\
\hline
\end{tabular}


Novia Wijaya, Lusia Savitri Setyo Utami: Pengaruh Penyampaian Informasi pada Aplikasi TikTok terhadap Perilaku Konsumtif Generasi Z

\begin{tabular}{llll}
\hline P13 & 0.655 & 0.00 & Valid \\
\hline P14 & 0.656 & 0.00 & Valid \\
\hline P15 & 0.769 & 0.00 & Valid \\
\hline P16 & 0.778 & 0.00 & Valid \\
\hline P17 & 0.607 & 0.00 & Valid \\
\hline P18 & 0.812 & 0.00 & Valid \\
\hline P19 & 0.758 & 0.00 & Valid \\
\hline P20 & 0.802 & 0.00 & Valid \\
\hline P21 & 0.768 & 0.00 & Valid \\
\hline P22 & 0.656 & 0.00 & Valid \\
\hline P23 & 0.778 & 0.00 & Valid \\
\hline P24 & 0.682 & 0.00 & Valid
\end{tabular}

Sumber: Olahan Data Peneliti

\section{Uji Validitas}

Berdasarkan hasil uji validitas di atas, nilai signifikansi adalah 0.00. Artinya, nilai signifikansi tersebut di bawah 0.05. Sehingga, dapat disimpulkan bahwa penelitian ini adalah valid karena nilai signifikansi di bawah 0.05 . Dari hasil penelitian tersebut juga menunjukan bahwa pernyataan-pernyataan dari setiap variabel dalam kuesioner tersebut sudah valid.

\section{Uji Reliabilitas}

\begin{tabular}{ccc} 
Variabel & $\begin{array}{c}\text { Tabel 2. Hasil Uji Reliabilitas } \\
\text { Cronbach's Alpha }\end{array}$ & Keterangan \\
\hline Penyampaian Informasi & 0.853 & Reliabel \\
\hline Perilaku Konsumtif & 0.928 & Reliabel \\
\hline
\end{tabular}

Sumber: Olahan Data Peneliti

Berdasarkan data di atas, uji reliabilitas pada variabel penyampaian informasi dan perilaku konsumtif dapat dikatakan reliabel karena cronbach's alpha di atas 0.6. Hasil penelitian juga menyimpulkan bahwa data penelitian tersebut memiliki relibialitas yang sangat tinggi.

\section{Uji Hipotesis (Uji t)}

Uji t bertujuan untuk menguji level signifikan dari bentuk pengaruh secara parsial atau terpisah antara variabel-variabel bebas terhadap variabel terikat. Uji t digunakan untuk menguji pengaruh variabel independen terhadap beberapa variabel dependen (Priyatno, 2010). Dalam uji hipotesis (uji t), H0 ditolak dan menerima H1 apabila signifikasinya di bawah 0.05 . 
Tabel 3. Hasil Uji t

Coefficients $^{\mathrm{a}}$

\begin{tabular}{|c|c|c|c|c|c|c|}
\hline \multirow[b]{2}{*}{ Mode } & & \multicolumn{2}{|c|}{$\begin{array}{l}\text { Unstandardized } \\
\text { Coefficients }\end{array}$} & $\begin{array}{l}\text { Standardized } \\
\text { Coefficients }\end{array}$ & \multirow[b]{2}{*}{$\mathrm{t}$} & \multirow[b]{2}{*}{ Sig. } \\
\hline & & $\mathrm{B}$ & Std. Error & Beta & & \\
\hline 1 & (Constant) & -16.108 & 6.530 & & -2.467 & .015 \\
\hline & $\begin{array}{l}\text { Penyampaian } \\
\text { Informasi }\end{array}$ & 1.358 & .162 & .612 & 8.397 & .000 \\
\hline
\end{tabular}

a. Dependent Variable: Perilaku Konsumtif

Sumber: Olahan Data Peneliti

Pada tabel di atas, nilai signifikansinya adalah 0.000. Maka, H0 ditolak dan menerima $\mathrm{H} 1$. Artinya, H0 yang menyatakan bahwa tidak ada pengaruh penyampaian informasi pada aplikasi TikTok terhadap perilaku konsumtif generasi Z ditolak dan $\mathrm{H} 1$ yang menyatakan bahwa ada pengaruh penyampaian informasi pada aplikasi TikTok terhadap perilaku konsumtif generasi $\mathrm{Z}$ diterima.

\section{Analisis Regresi Sederhana}

Hasil uji regresi linier digunakan untuk melihat perbedaan ukuran dan pengaruh variabel bebas (X) terhadap variabel terkait (Y) (Bungin, 2014). Dalam penelitian ini, digunakan uji regresi linier sederhana yang digunakan untuk menguji bagaimana pengaruh variabel bebas $(\mathrm{X})$ terhadap variabel terkait (Y).

Dalam penelitian ini, digunakan uji regresi linier sederhana yang digunakan untuk menguji bagaimana pengaruh variabel bebas (X) terhadap variabel terkait (Y). Rumus dari analisis regresi sederhana adalah:

$$
\mathrm{Y}=\mathrm{a}+\mathrm{bX}
$$

Tabel 4. Hasil Analisis Regresi Sederhana Coefficients $^{\mathrm{a}}$

\begin{tabular}{|c|c|c|c|c|c|c|}
\hline \multirow[b]{2}{*}{ Mode } & & \multicolumn{2}{|c|}{$\begin{array}{l}\text { Unstandardized } \\
\text { Coefficients }\end{array}$} & $\begin{array}{l}\text { Standardized } \\
\text { Coefficients }\end{array}$ & \multirow[b]{2}{*}{$\mathrm{t}$} & \multirow[b]{2}{*}{ Sig. } \\
\hline & & B & Std. Error & Beta & & \\
\hline \multirow[t]{2}{*}{1} & (Constant) & -16.108 & 6.530 & & -2.467 & .015 \\
\hline & $\begin{array}{l}\text { Penyampaian } \\
\text { Informasi }\end{array}$ & 1.358 & .162 & .612 & 8.397 & .000 \\
\hline
\end{tabular}

a. Dependent Variable: Perilaku Konsumtif Sumber: Olahan Data Peneliti

Dari tabel di atas, maka analisis regresi sederhana adalah:

$$
Y=\mathbf{- 1 6 . 1 0 8}+\mathbf{( 1 . 3 5 8 ) X}
$$

$\mathrm{Y}$ adalah variabel $\mathrm{Y}$ dan $\mathrm{X}$ adalah variabel $\mathrm{X}$. Apabila nilai X bertambah, maka akan mempengaruhi nilai $Y$. Analisis regresi sederhana membuktikan besarnya pengaruh antara variabel penyampaian informasi terhadap perilaku konsumtif. 
Novia Wijaya, Lusia Savitri Setyo Utami: Pengaruh Penyampaian Informasi pada Aplikasi TikTok terhadap Perilaku Konsumtif Generasi Z

\section{Uji Normalitas}

Uji normalitas merupakan pengujian yang dilakukan sebelum melakukan pengolahan data untuk memastikan bahwa data yang digunakan berdistribusi normal (Creswell, 2012). Dasar pengambilan keputusannya adalah dengan menggunakan plot probabilitas normal, yaitu jika titik-titik tersebar di sekitar garis lurus dan mengikuti garis diagonal, maka regresi tersebut memiliki asumsi normalitas.

Gambar 2. Hasil Uji Normalitas

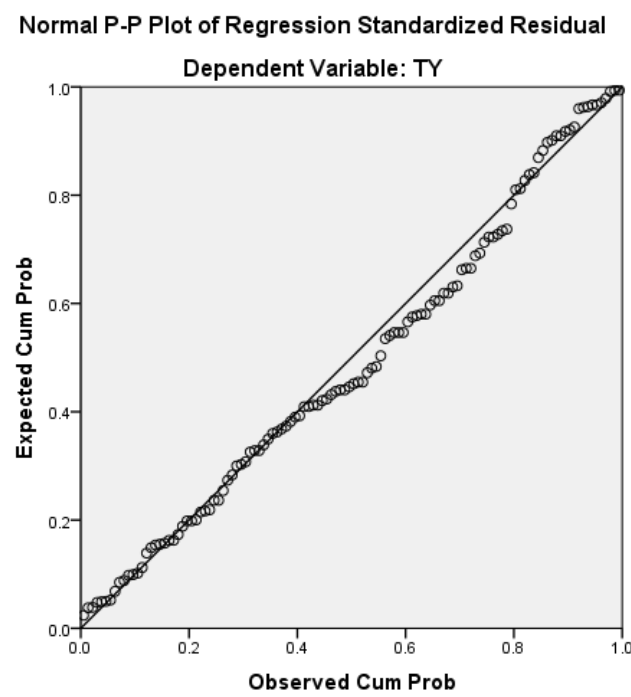

Sumber: Olahan Data Peneliti

Pada gambar di atas, terlihat bahwa titik-titik menyebar di sekitar garis diagonal dan penyebarannya mengikuti arah garis diagonal. Maka dari itu, dapat disimpulkan bahwa model garis regresi ini berdistribusi normal dan sudah memenuhi asumsi normalitas. Sehingga, data pada pengaruh penyampaian informasi pada aplikasi TikTok terhadap perilaku konsumtif generasi $\mathrm{Z}$ berdistribusi normal.

\section{Koefisien Determinasi (Uji R)}

Pengujian koefisien determinasi bertujuan untuk mengetahui seberapa banyak variabel independen yang dapat ditampilkan dalam SPSS untuk menjelaskan kemampuan variabel dependen.

Tabel 5. Hasil Koefisien Determinasi (Uji R)

Model Summary ${ }^{b}$

\begin{tabular}{ccccc}
\hline Model & $\mathrm{R}$ & R Square & $\begin{array}{c}\text { Adjusted R } \\
\text { Square }\end{array}$ & $\begin{array}{c}\text { Std. Error of } \\
\text { the Estimate }\end{array}$ \\
\hline 1 & $.612^{\mathrm{a}}$ & .374 & .369 & 9.92962 \\
\hline
\end{tabular}

a. Predictors: (Constant), Penyampaian Informasi

b. Dependent Variable: Perilaku Konsumtif

Sumber: Olahan Data Peneliti 
Dilihat dari hasil tabel model summary, variabel penyampaian informasi mempengaruhi sebesar $37.4 \%$ terhadap variabel perilaku konsumtif. Nilai koefisien determinasi dilihat dari R Square sebesar 0.374 atau $37.4 \%$. Dari hasil uji R, artinya terdapat pengaruh sebesar $37.4 \%$ antara variabel penyampaian informasi terhadap variabel perilaku konsumtif. Hal tersebut menunjukan bahwa penyampaian informasi pada aplikasi TikTok mampu memberikan pengaruh sebesar $37.4 \%$ terhadap perilaku konsumtif generasi Z. Sisanya sebesar $62.6 \%$ dipengaruhi oleh variabel lainnya yang tidak diteliti dalam penelitian ini.

Hasil survey yang paling berpengaruh pada variabel penyampaian informasi adalah responden yang merasa konten rekomendasi yang disampaikan oleh content creator pada aplikasi TikTok mengandung informasi yang lengkap mengenai hal-hal yang ingin diketahui, seperti kualitas dan harganya. Selain itu, responden juga merasa bahwa penyampaian content creator mengenai konten rekomendasi pada aplikasi TikTok jelas. Kedua pernyataan tersebut mendapatkan jawaban setuju sebesar 58.3\%.

Hasil survey yang paling dipengaruhi untuk variabel perilaku konsumtif adalah responden yang merasa mereka membeli produk karena tertarik oleh rekomendasi dari content creator pada aplikasi TikTok. Pernyataan tersebut mendapatkan jawaban setuju sebesar $42.5 \%$. Selanjutnya, sebesar $27.5 \%$ responden juga setuju bahwa mereka mengikuti mode untuk menjaga penampilan mereka. Artinya, variabel X (penyampaian informasi) pada dimensi kejelasan informasi sangat berpengaruh pada variabel Y (perilaku konsumtif) pada dimensi inefisiensi biaya dan dimensi mengikuti mode. Maka, suatu konten yang disampaikan harus mengandung informasi yang jelas, sehingga konsumen dapat mengerti mode terbaru dan menarik perhatian mereka untuk membeli produk tersebut.

Dalam Teori Integrasi Informasi (Information Integration Theory), dapat disimpulkan bahwa penyampaian informasi telah berhasil mengubah sikap generasi $\mathrm{Z}$ dalam penelitian ini. Maka dari itu, informasi yang lengkap mengenai konten rekomendasi pada aplikasi TikTok yang jelas dan hal-hal yang ingin diketahui, seperti kualitas dan harganya adalah hal yang penting karena mendapatkan persentase terbesar, yaitu sebesar $58.3 \%$. Penelitian ini juga membuktikan bahwa komunikasi pemasaran terpadu pada aplikasi TikTok yang dilakukan oleh content creator tersampaikan kepada generasi Z karena pemasaran tersebut juga mempengaruhi sikap dan perilaku generasi Z. Dalam hasil kuesioner, produk yang dipromosikan pada aplikasi TikTok secara jelas, menarik, lengkap (mengenai kualitas, harga), sesuai fakta, akan mempengaruhi sikap generasi $\mathrm{Z}$ dalam membeli barang tersebut.

Salah satu dari enam model komunikasi adalah Digital Marketing. Pada penelitian ini, penyampaian informasi menggunakan jejaring sosial TikTok. Pembuktiannya dapat dilihat dalam hasil kuesioner yang membuktikan bahwa penyampaian informasi pada aplikasi TikTok mempengaruhi perilaku konsumtif generasi Z sebesar 37.4\%. Hasil tersebut juga membuktikan bahwa social media marketing pada aplikasi TikTok berhasil mengubah sikap konsumen mengenai produk yang dipasarkan pada aplikasi TikTok. Maka, dari hasil penelitian tersebut, terbukti bahwa penyampaian informasi pada aplikasi TikTok mempengaruhi perilaku konsumtif generasi $\mathrm{Z}$ karena hasil uji $\mathrm{R}$ yang membuktikan terdapat pengaruh sebesar $37.4 \%$ antara variabel penyampaian informasi terhadap variabel perilaku konsumtif. 
Novia Wijaya, Lusia Savitri Setyo Utami: Pengaruh Penyampaian Informasi pada Aplikasi TikTok terhadap Perilaku Konsumtif Generasi Z

\section{Simpulan}

Berdasarkan dari penelitian ini, peneliti memiliki tujuan untuk mengetahui ada atau tidaknya pengaruh penyampaian informasi pada aplikasi TikTok terhadap perilaku konsumtif generasi $\mathrm{Z}$ dan seberapa besar pengaruh tersebut. Maka, ada beberapa hal yang dapat disimpulkan oleh peneliti, yaitu penyampaian informasi berpengaruh signifikan terhadap perilaku konsumtif generasi Z. Uji hipotesis pada penelitian ini menyatakan $\mathrm{H} 0$ ditolak dan $\mathrm{H} 1$ diterima. Artinya, penyampaian informasi pada aplikasi TikTok berpengaruh terhadap perilaku konsumtif generasi Z. Dalam pengaruh penyampaian informasi pada aplikasi TikTok terhadap perilaku konsumtif generasi $\mathrm{Z}$, dimensi yang paling mempengaruhi dalam variabel penyampaian informasi adalah dimensi kejelasan informasi. Dimensi yang paling dipengaruhi dalam variabel perilaku konsumtif adalah dimensi inefisiensi biaya dan mengikuti mode.

Peneliti menyarankan agar para content creator selalu mengembangkan kreativitas dari produk yang akan dipasarkan melalui media sosial dan memastikan juga agar produk tersebut tepat sesuai target sasaran. Selain itu, peneliti juga menyarankan untuk penelitian selanjutnya agar dapat meneliti lebih dalam mengenai bagaimana meningkatkan brand awareness dalam suatu konten dan kreativitas konten seperti apa yang dapat memberi pengaruh pada perilaku konsumtif.

\section{Ucapan Terima Kasih}

Penulis ingin menyampaikan rasa terima kasih kepada Universitas Tarumanagara yang telah mendukung proses berjalannya penelitian ini.

\section{Daftar Pustaka}

Aryani, D., \& Rosinta, F. (2010). Pengaruh Kualitas Layanan terhadap Kepuasan Pelanggan dalam Membentuk Loyalitas Pelanggan. Jurnal Ilmu Administrasi dan Organisasi, 17, 114-126.

Astuti, E. D. (2013). Perilaku Konsumtif dalam Membeli Barang Pada Ibu Rumah Tangga Di Kota Samarinda. eJournal Psikologi. 1(2), 148-156.

Liputan6.com. (2020, Agustus 12). Apa yang Membuat TikTok Disukai Generasi Z?. Retrieved September 14, 2020, from Liputan6 Online: https://www.liputan6.com/tekno/read/4328268/apa-yang-membuat-tiktokdisukai-generasi-z

Liputan6.com. (2020, September 01). Viral di TikTok, Produk Kosmetik Lokal Kebanjiran Order. Retrieved September 29, 2020, from Liputan6 Online: https://www.liputan6.com/lifestyle/read/4340636/viral-di-tiktok-produkkosmetik-lokal-kebanjiran-order

Prayitno, Duwi. (2010). Paham Analisa Data Statistik Dengan SPSS. Yogyakarta: MediaKom,

Sugiyono, D. (2010). Metode penelitian kuantitatif dan R\&D. Bandung: Alfabeta.

TikTok.com. Retrieved September 18, 2020, from TikTok Website: https://www.tiktok.com/about?lang=en 
Vol. 5, No. 2, Oktober 2021, Hal 267-276

Utomo, A, H. (2020, Februari 28). Membaca Peta Pengguna TikTok dan Aplikasi Media Sosial Lain di Indonesia. Retrieved September 14, 2020, from Kompasiana Online:

https://www.kompasiana.com/arisheruutomo/5e58c3edd541df2396062422/mem baca-peta-pengguna-tiktok-dan-aplikasi-media-sosial-lain-diindonesia?page=all\#section2 